\title{
THE EFFECTS OF PRE-QUESTION STRATEGY ON THE READING COMPREHENSION ACHIEVEMENT OF THE SECOND GRADE STUDENTS AT SMA NEGERI 1 BANTAENG Efek Strategy Pre-question terhadap Prestasi Pemahaman Membaca Siswa Kelas 2 SMA Negeri 1 Bantaeng
}

\author{
Awaliah Azis \\ English Education Department, Faculty of Teacher Training and Education \\ Muhammadiyah University of Makassar \\ awaliahazis@gmail.com \\ Rezky Darmayani \\ English Education Department, Faculty of Teacher Training and Education \\ Muhammadiyah University of Makassar
}

\begin{abstract}
The objective of this research was to find out the significant effect of Pre-question Strategy on the reading comprehension. The strategy employed in this research was Quasi-Experimental method involved two groups of students. The research population was the second year students of SMA Negeri 1 Bantaeng, consisted of population about 270 students and the sample was 60 students. The sampling strategy used was cluster random sampling strategy. The result of data analysis shows that at the level of significance 0.05 with degrees of freedom $(d f)=n_{1}+n_{2}-2$ where $n=58$, there was a significant effect on the reading comprehension of the students who used Pre-questioning strategy. It was proved by the result that the mean score of experimental class (77.7) which was taught used Pre-question was higher that the mean score of control class (55.2), which without Pre-question. Way were t-test value was higher than t-table value (7.,12>2,000). It means that an alternative hypothesis was accepted and the null hypothesis was rejected. Based on the result above, the writer draws conclusion that the using of Pre-questioning strategy was effective to improve the students' reading comprehension.
\end{abstract}

Keywords: Reading, Pre-question, strategy, achievement, comprehension

\begin{abstract}
ABSTRAK
Tujuan dari penelitian ini adalah untuk mencari signifikansi dari efek straegy Pre-question terhadap pemahaman membaca. Strategy menggunakan metode penelitian Kuasi-Eksperimen yang melibatkan dua grup siswa. Populasi dalam penelitian adalah siswa kelas 2 SMA Negeri 1 Bantaeng, terdiri atas populasi sekitar 270 siswa dan sampel 60 siswa. Strategy sampel digunakan acak kelompok. Hasil dari analisis data memperlihatkan tingkat yang signifikan 0,05 dengan $(d f)=n_{1}+n_{2}-2$ dimana $n=58$, terdapat sebuah hal efek signifikan terhadap pemahaman membaca dari siswa yang menggunakan strategy Prequestioning. Hal itu dibuktikan dengan nilai rata-rata dari kelas eksperimental $(77,7)$ yang mana diajarkan dengan menggunakan Pre-questioning lebih tinggi dibanding dengan nilai rata-rata kelas kontrol (55,2) tanpa strategy Prequestioning. Adapun caranya ditempuh dengan hasil t-test lebih tinggi daripada nilai t-table (7,12>2,000). Itu mengartikan bahwa sebuah perkiraan alternatif diterima dan perkiraan gagal ditolak. Berdasarkan dari hasil di atas, penulis menggambarkan kesimpulan bahwa dengan menggunakan strategy Prequestioning adalah efektif untuk meningkatkan pemahaman membaca siswa.
\end{abstract}


Kata Kunci: Membaca, Pre-question, strategi, prestasi, pemahaman

\section{INTRODUCTION}

In English, there were four skills that should be mastered, they were: listening, speaking, reading, and writing. The reading skill became very important in the education field, students need to be exercised and trained in order to have a good reading skill. Reading is also something crucial and indispensable for the students because the success of their study depends on the greater part of their ability to read. If their reading skill is poor they were very likely to fail in their study or at least they will have difficulty in making progress. On the other hand, if they have a good ability in reading, they will have a better chance to succeed in their study.

In reading, to comprehend the text the readers should be able to manage every part of the text, because it is easy to gain the comprehension in reading when the readers were able to organize the text. Sometimes, they may find form of Pre-question and it is important for them to comprehend a reading text with having knowledge in general view of the text. Theoretically, Pre-question itself can build the students' interest and motivation before students read the whole text. Moreover, the students can predict what will be discussed on the text. In line with this study, students may improve their reading comprehension if they know about Pre-question and it is very important to understand about Pre-question in order to get good comprehension in reading.

Based on the explanation above, the writer is interested in finding out the effects of treatment with Pre-question on students' reading comprehension achievement and concluded that the Pre-question consist of some questions provided before the students read the whole text. It tends to build the students' interest and motivation to read the text. 


\section{MATERIALS AND METHOD}

A. Materials

\section{Definition of Reading}

Reading is an active and interactive activity to reproduce the word mentally and vocally and tries to understand the content of reading text. It is important to bear in mind that reading is not an invariant skill, that there were different types of reading skills, which correspond to the many different purposes we have for reading. In classroom, in student's reading activities, the writer is sure that they have many purposes, among others were to graduate from their school and to provide themselves with the knowledge to continue their studies whatever their purposes were. In order to achieve the goal, the comprehension ability in reading is needed. According to Olson and Diller (1982:42) in Henni (2001: 17), reading comprehension is a term used to identify those skills needed to understand and apply information contained in a written material.

Reading very complex process to learn and to teach, it involves eye and brain Harmer ( 1991:190) stated that reading is exercise dominated by eye and brain, eye looks at the massage in that printed pages then sent in the brain, then the brain processes the significance of the massage Smith (1980: 128) also argue that, reading is both a visual comes from in front of the eye ball( what the eye seen) that is printed pages, then non-visual type comes from behind eye bal, that is the brain( here the brain processes what the eye have seen).

Further Simanjuntak (1988: 3) in indo Lallo (2002: 6) states reading is process of putting the reader in contact and communication with ideas. In his case the firm point to be made the reading process in reading comprehension, knowledge in the basic element for comprehension.Reading in the context is not just reading as kind of transfer from written to a sound like reading aloud, but reading established with understanding the meaning of words, sentences, and paragraph sensing relationship among the ideas. Chamber and Lawry in Yusuf (1993) pointed out that the reading is more than merely recognizing the words for which certain combination of letters bring about correct recall. It 
includes the whole range of thinking responses those thinking responses and feeling defining some need, identifying.

\section{Concept of Pre-Question}

Based on Brown's (2001), Pre-question is some questions which were provided before the students read the whole text, in order to build the reading schemata and background knowledge of the students and also to raise their interest, and their cognitive aspect to predict what will face by them in the next whole text. He also defined Pre-question implicitly as some questions which were provided before the students read the whole text, in order to build the students' interest and motivation, also their cognitive factors and Prequestion is very useful to activate the schemata, thus the students can predict what will be faced by them in the reading text.

Wiesendanger and Wolleberg 1978 state that pre-question cause students to focus on obtaining answer the particular questions, and that this may in turn lower the overall reading comprehension of a given a work. Prequestion before reading is effect the reading process among older readers as well.

Pre-question is very important for the reader because the reader to comprehend a reading text with having knowledge in general of view of the text, with Pre-question it self can build the students interest and motivation in reading and the reader or student know about the particular topic before reading the topic.

a. Kinds of Pre-question

According to Harmer (1985:153), there were some kinds of Pre-question, they were: Pre-question before reading to confirm expectations, Pre-question before reading to extract specific information, Pre-question before reading for general comprehension, and Pre-question before reading for detail comprehension. The explanations were as following:

1) Pre-question before reading to confirm expectations

The use of Pre-question as a tool for placing great emphasis on the lead-in stage (where students were encouraged to become interested in the subject matter of the text), encourages students to predict the 
content of the text, and gives them an interesting and motivating purpose for reading.

2) Pre-question before reading to extract specific information

Pre-question as a tool to force the students to extract specific information from the text. They were going to answer before reading the text. If they do this it will be possible for them to read in the required way, they should seen the text only to extract the information the questions demand.

3) Pre-question before reading for general comprehension

In this case, Pre-question used to build up the students' prior knowledge.

4) Pre-question before reading for detailed comprehension

This kind of Pre-question intends to give the students some detailed information that should be found by them in the whole of the text.

Based on the explanation above, in this study the writer only concern two kinds of Pre-question, they were: Pre-question before reading for general comprehension and the Pre-question before reading to confirm expectations. In order to deal with students' background knowledge and activating schemata. Related to this study, the writer used Pre-question with Indonesian version, because the form of Pre-question is only to deal the students' background knowledge. Thus, the students can predict easily what will be discussed on the text, after they read and answer the Pre-question.

\section{Benefit of Pre-question}

Carrel, (1899) states that the benefit of pre-question can help the students to comprehend the reading text and students have been though about how to identify main idea and pre-question can build the students in interest and motivation before students read the whole text, make the reader or students to focus and attention an particular topic, with pre-question before reading. The students can explain their ideas from their prior experiences and their knowledge about the topic that they will learn. The students can predict what will be 
discussed on the text. Pre-question can make the students reading comprehension will better, and improve their skill comprehending about the text.

\section{The Purpose of Pre-question}

Mige karakas (1899:2) state that pre-question function to motivate students to read what follows for a purpose that is so gain requisite information to answer the question. Being motivated is one of the most important factors that can help the students in the purpose of reading.

The purpose of posing questions before reading is the reader to:

a. Elicit prior knowledge related to the core ideas of the text

b. Make connection between what they know and the subject of the text

c. Set a purpose for reading

d. Constructs predictions

\section{Questioning Strategies}

The most important key to create an interactive learning is the initiation of interaction from the teacher by using question, Brown (2001:169). Appropriate questioning can fulfill a number of different functions, such as:

a. Teacher questions give students the opportunity to produce language comfortably without having to risk initiating language themselves. It is very scary for the students to have to initiate conversation or topics for discussion.

b. Teacher question can serve to initiate a chain reaction of students interaction among themselves.

c. Teacher questions giving immediate feedback about students' comprehension.

d. Teacher questions provide students with opportunities to find out what they think. As they were nudged into responding to questions about, say, a reading, they can discover what their own opinions and reactions were. This self-discovery can be especially useful for a pre-reading activity.

Perhaps the simplest way to conceptualize the possibilities is to think of a range of questions, beginning with display questions that attempt to elicit information already known by the teacher and the students. In this study, the 
writer interested to use Pre-question in order to make the general frame of the knowledge.

\section{B. Theoretical Framework}

The theoretical framework of this research, which has been done, served in the following diagram:

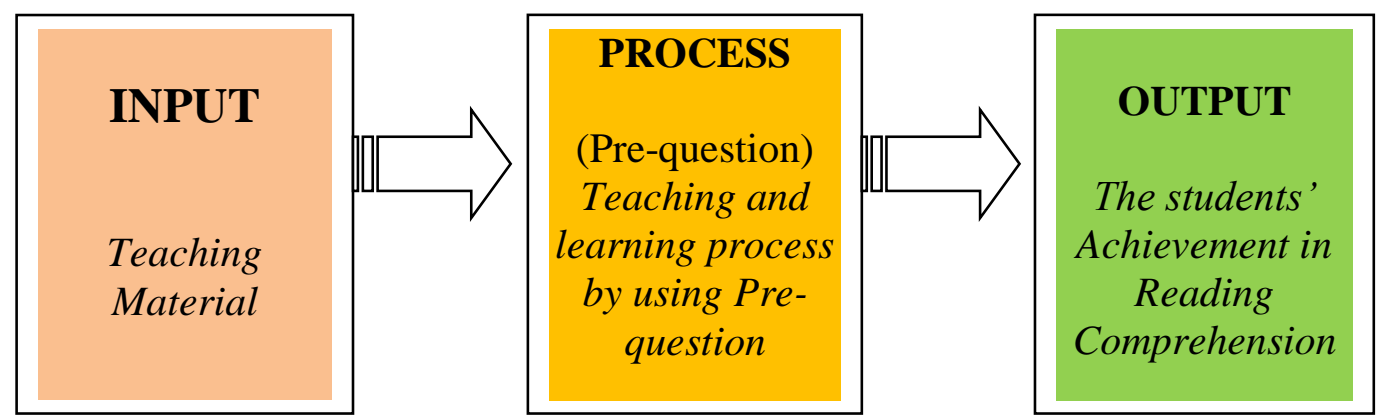

\section{RESEARCH METHODOLOGY}

This research employs Quasi-experimental design in which two groups were involved. They were experimental group and control group. Pre-test is administered before treatment while post-test is administered after treatment to measure its effect. The purpose of the research is to find out the effect of using Pre-question in reading comprehension. This design can be present as follows:

\begin{tabular}{|cccc|}
\hline $\mathrm{E}$ & $\mathrm{O}_{1}$ & $\mathrm{X}_{1}$ & $\mathrm{O}_{2}$ \\
$\mathrm{C}$ & $\mathrm{O}_{2}$ & $\mathrm{X}_{2}$ & $\mathrm{O}_{2}$ \\
\hline
\end{tabular}

(Gay, 1981)

Where : E : Experimental group

C : Control group

$\mathrm{O}_{1} \quad$ : Pre-test

$\mathrm{O}_{2} \quad$ : Post-test

$\mathrm{X}_{1} \quad$ : Treatment Pre-question for the experimental group

$\mathrm{X}_{2} \quad$ : Treatment without Pre-question for the control group

\section{A. Research Variables and Indicator}

The variables were namely independent and dependent variables. Independent variable is the application of Pre-question to the student, while 
dependent variable is the students' literal reading comprehension. The indicator of literal reading comprehension is the main idea and detail information.

\section{B. Hypothesis}

Based on the review of related literature and some findings above, the researcher formulates as follow:

: There is significant effect of Pre-question on the reading comprehension achievement of second grade students of SMA Negeri 1 Bantaeng.

$\left(\mathrm{H}_{1}\right) \quad$ : There is no significant effect of Pre-question on the reading comprehension achievement of second grade students of SMA Negeri 1 Bantaeng.

\section{Population and Sample}

The population of this research is all the second grade students of SMA Negeri 1 Bantaeng in academic year 2012. The number of population is about 270 students spread in to 7 classes. This research will use cluster random sampling technique. Due to the total of population is big, the researcher took two classes randomly, IPS class XI.2 as experimental group and IPS class XI.3 as control group. Each group consists of 30 students.

\section{Instrument of Research}

The instrument of the research is a reading test use in pretest and posttest. The kinds of test will be given is essay test. The pretest was give before the application of Pre-question technique in the class, so that the researcher is able to know the ability of the students in reading comprehension, while the posttest is give after the treatment of applying Pre-question technique as the teaching strategy as to assess and examine the students reading comprehension both pretest and posttest were use to find out the development of the students after being treated by the Pre-question technique.

\section{E. Procedure of Collecting Data}


For the first meeting, both groups experiment and controlled were given pretest. The researcher give reading test to find the students' achievement before giving treatment. The test allocated about 90 minutes. The procedures were:

a. The researcher distributed the test materials to the students.

b. The researcher gives direction of the test to the students.

c. The researcher controls the students when they do the test.

d. The researcher collects worksheet of the student after the test.

The treatment is done after pretest. The techniques of treatments use to teach the groups were different from one group to another, where the experimental group will teach by using Pre-question technique and the control group will teach by using verbal explanation (conventional way).

In treatments, the researcher teaches by Pre-question. These steps were done for four meetings. Each meeting has time 90 minutes. The procedures of conducting treatment were presented as follows:

1. The researcher tells the students what they should do at the meeting.

2. The researcher divides the students into groups. The number in each group depends on the number of subtopics.

3. The researcher will give each member of the group a section or portion of the material.

4. The researcher asks each student meets with the members of the other groups who have the same assigned section forming an expert group.

5. The researcher asks the expert group learns the material together and decides on how to teach the material to the original groups.

6. After discussing in expert group the researcher asks the students return to their original groups.

7. The researcher asks an expert in one of the different whereas of the topics being studied, and teaches their were of expertise to the other group members.

8. The researcher will give a quiz in the end. At that time, no team members may help each other.

\section{b. Control group}

1) The researcher distributes a text to the students. 
2) The students read the passages will give by their researcher for 15 Minutes.

3) The researcher explains the passages to the students. The students were not divided into groups; they discuss the reading passages with the setting of classroom.

4) The researcher gets the students answer the list of question based on the text given.

5) Then, the researcher corrected the answers.

\section{F. Technique of Data Analysis}

The data obtained from the test is analyzed by using the procedures as follows:

1. Scoring the students' correct answer at pretest and posttest by using this formula: $\quad \frac{\text { Student's Correct Answer Score }}{\text { The total number of items }} \times 100$

Score $=$

2. Classifying the students' score into seven classifications:

\begin{tabular}{|l|l|}
\hline Score & Classification \\
\hline $91-100$ & very good \\
\hline $75-90$ & Good \\
\hline $61-74$ & Fair \\
\hline $51-60$ & Poor \\
\hline less than 50 & \multicolumn{2}{c}{ very poor } \\
\hline
\end{tabular}

2. Computing the frequency and rate percentage of students' score:

$$
P=\frac{F}{N} \mathrm{X} 100 \%
$$

Where: $\quad \mathrm{P}=$ Percentage

$$
\mathrm{N}=\text { Total number of student }
$$

$\mathrm{F}=$ Frequency

(Mason \& Bramble, 1978) 
3. Calculating the mean score of students' answer in both pretest and posttest by this formula : $\quad \bar{x}=\frac{\sum x}{N}$

$$
\text { Note }: \quad \begin{aligned}
\bar{x} & =\text { Mean } \\
\sum x & =\text { The Sum of all Score } \\
\mathrm{N} & =\text { Number of Subject }
\end{aligned}
$$

1981)

(Gay

4. Finding standard deviation of the students pretest and posttest by applying

$$
\begin{aligned}
& \text { formula below: } S D=\frac{\sqrt{\sum x^{2}-\frac{\left(\sum x\right)^{2}}{N}}}{N-1} \\
& \text { Note : } \quad \begin{aligned}
\mathrm{SD} & =\text { Standard Deviation } \\
\sum x & =\text { Sum of all Score } \\
\sum x^{2} & =\text { Sum Squeeze of all Score } \\
\mathrm{N} & =\text { Number of Student }
\end{aligned}
\end{aligned}
$$

(Gay 1981)

5. To find out whether the differences between pre-test and post-test value is significant, the following t-test formula is use:

$$
\begin{array}{ll}
t=\frac{\bar{x} 1-\bar{x} 2}{\sqrt{\left(\frac{\mathrm{SS} 1+\mathrm{SS} 2}{\mathrm{n} 1+\mathrm{n} 2-2}\right)\left(\frac{1}{\mathrm{n} 1}+\frac{1}{\mathrm{n} 2}\right)}} & \\
\text { Note: } \mathrm{t} \quad & \text { Test of significance } \\
\bar{x}_{1}= & \text { Mean score of experimental group } \\
\bar{x}_{2}= & \text { Mean score of control group } \\
\mathrm{SS}_{1}= & \text { Sum square of experimental group } \\
\mathrm{SS}_{2}= & \text { Sum square of control group } \\
\mathrm{n}_{1}= & \text { Number of students of experimental group } \\
\mathrm{n}_{2}= & \text { Number of students of control group } \\
\text { Where: } & S S 1=\sum X 1^{2}-\frac{\left(\sum X 1\right)^{2}}{n 1} \\
& S S 2=\sum X 2^{2}-\frac{\left(\sum X 2\right)^{2}}{n 2}
\end{array}
$$

(Gay 1981: 327) 


\section{FINDINGS AND DISCUSSION}

This chapter deals with two sections. The first section deals with research findings. The findings of this research cover the description of the result of data analysis through test. The second section deals with discussion.

\section{The Effect of Pre-question on the Reading Comprehension}

Teaching reading comprehension by used Pre-question Strategy had positive effect. It was indicated the mean score for experimental group higher than control group with progress for experimental group $30 \%$ and control group $2 \%$.

2. The Mean Score and Standard Deviation of Pretest and Posttest

\begin{tabular}{|l|l|l|l|l|l|l|}
\hline \multirow{2}{*}{ No } & \multirow{2}{*}{ Group } & \multicolumn{2}{|l|}{ Mean Score } & \multicolumn{2}{l|}{ Standard Deviation } & \multirow{2}{*}{ Progress } \\
\cline { 3 - 6 } & & Pre-test & Post-test & Pre-test & Post-test & \\
\hline 1 & Experimental & 59.3 & 77.4 & 11.12 & 11.98 & $31 \%$ \\
\hline 2 & Control & 55.2 & 56.4 & 12.14 & 12.45 & $2 \%$ \\
\hline
\end{tabular}

Table 1 shows the mean score and standard deviation of both control and experimental class in pretest and posttest. For the control class, the mean score was 55.2 and the standard deviation was 12.14 in pretest. In posttest, the mean score was 56.4 and the standard deviation was 12.45 . The mean score for the experimental class was 59.30 and the standard deviation was 11.12 in pretest. While in posttest, the mean score was 77.4 and the standard deviation was 11.98

1. The Rate Percentage of Pretest \& Posttest

\begin{tabular}{|c|c|c|c|c|c|c|c|c|c|c|}
\hline \multirow{3}{*}{ No. } & \multirow{3}{*}{ Classification } & \multirow{3}{*}{ Score } & \multicolumn{4}{|c|}{ Control Group } & \multicolumn{4}{|c|}{ Experimental Group } \\
\hline & & & \multicolumn{2}{|c|}{ Pretest } & \multicolumn{2}{|c|}{ Posttest } & \multicolumn{2}{|c|}{ Pretest } & \multicolumn{2}{|c|}{ Posttest } \\
\hline & & & $\mathbf{F}$ & $\%$ & $\mathbf{F}$ & $\%$ & $\mathbf{F}$ & $\%$ & $\mathbf{F}$ & $\%$ \\
\hline 1. & Very Good & $91-100$ & - & & - & & - & & 4 & 13 \\
\hline 2. & Good & $75-90$ & 2 & 7 & 1 & 3 & 1 & 3 & 11 & 37 \\
\hline 3. & Fair & $61-74$ & 10 & 33 & 7 & 23 & 10 & 33 & 12 & 40 \\
\hline 4. & Poor & $51-60$ & 6 & 20 & 11 & 37 & 9 & 31 & 3 & 10 \\
\hline 5. & Very Poor & $<50$ & 12 & 40 & 11 & 37 & 10 & 33 & - & - \\
\hline \multicolumn{3}{|c|}{ Total } & 30 & 100 & 30 & 100 & 30 & 100 & 30 & 100 \\
\hline
\end{tabular}


In order to give clear description, the researcher also present the result of postest in chart below.

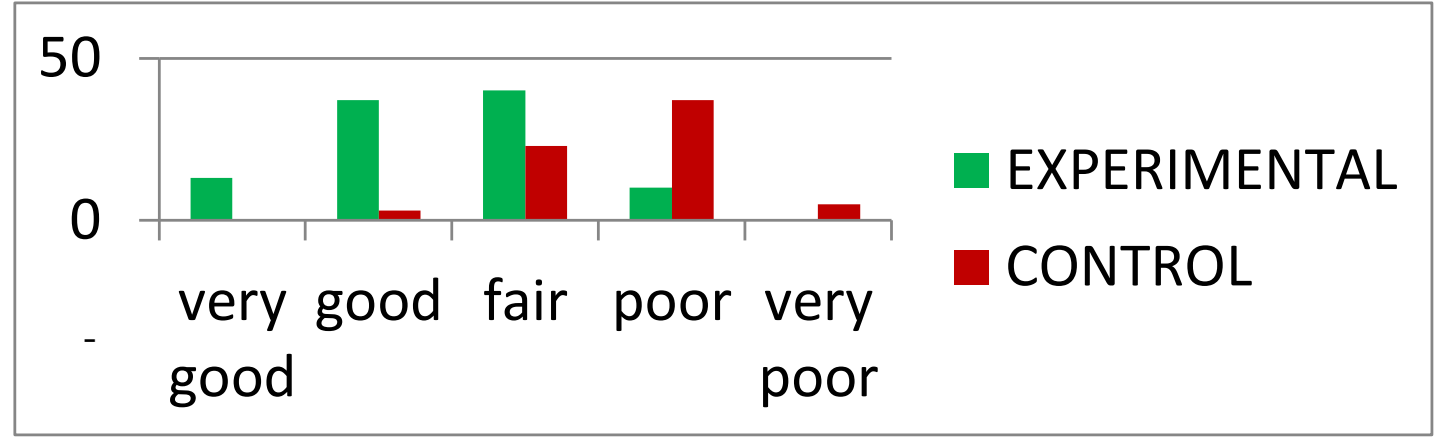

- Based on the table above, we can see the result of both control and experimental class. In control class, there was no significant increase of students' score in pretest and posttest. No student got "very good" in both pretest and posttest. 2 students (7\%) got "good" classification in pretest, but decreased to 1 student (3\%) in posttest. Then, 10 students (33\%) got "fair" in pretest and 7 students (23\%) got the same classification in posttest. For "poor" classification, 6 students $(20 \%)$ got the classification in pretest, and 11 students (37\%) got it in posttest. Then, there were 12 students (40\%) got "very poor" classification in pretest and 11 students (37\%) got it in posttest. Overall, the students' score of control class moved in quite same range in both pretest and posttest.

- In experimental class, the table shows a great movement of students' score. In pretest, there was no student got "very good" classification. But in posttest, 4 students (13\%) got the highest classification. For "good" classification, there was 1 student (3\%) got it in pretest and 11 students (37\%) got it in posttest. Then, 10 students (33\%) got "fair" classification in pretest and 12 students (40\%) got it in posttest. For “poor" classification, 9 students (31\%) got it in pretest and 3 students $(10 \%)$ got it in post test. The last, "very poor" classification, 10 students (33\%) got it in pretest and no one got it in post test. The result shows that the Cooperative Learning type Numbered Heads Together 
which was applied in experimental class, can increase students' reading comprehension achievement.

\section{T-test Value}

\begin{tabular}{|l|l|l|}
\hline Variable & T-test Value & T-table Value \\
\hline Pretest & 1.43 & 2.000 \\
\hline Posttest & 7.12 & 2.000 \\
\hline
\end{tabular}

Based on the table, the t-test value was 1.43 and the t-table value was 2.000 in pretest. It shows that the t-test value was smaller than t-table value $(1.43<$ 2.000). It indicates that there was no significant difference of mean scores in pretest between control and experimental class.

In posttest, the t-test value was 7.12 and the t-table value was 2.000 . It shows that the t-test value was higher than the t-table value $(7.12<2.000)$. This result indicates that there is a significant difference of mean scores in posttest between control and experimental class. It also conveys that null hypothesis (H0) was rejected and alternative hypothesis (H1) was accepted. It means that there are effect of Pre-Question Strategy for students' reading Comprehension Achievement.

\section{DISCUSSION}

In the previous chapter, the mean score of pretest of two groups were almost statisticaly the same. It means both experimental and control group have an equal reading comprehension ability before treatment. The techniques of treatments used to teach the groups were different from one group to another, where the experimental group was taught by using Pre-question strategy and the control group without Pre-question.

Fortunately, both groups of students made progress in reading after they were taught with different treatment. This means that both the application of Prequestion strategy and without Pre-question could make the students successful in reading. In addition, the use of Pre-question strategy could change the category of the students from very poor into very good (for experimental group). Meanwhile, 
without Pre-question could change the category of the students from very poor into good (for control group).

Although both groups made the progress in reading as a result of the two teaching techniques, but could not be said that both groups have the same power in improving students' reading comprehension. It is believed that the differences of students' reading comprehension after treatment are influenced by treatment given to them. It was proven by mean score of both experimental and control group. Therefore, it can be concluded that there was a significant difference of reading comprehension between students who were taught by using Pre-question strategy and those taught without Pre-question.

Based on the description above, the writer concludes that Pre-question strategy is as an effective which can be applied in improving the students' reading comprehension in the classroom learning because this technique can reduce monotonous situation and make students enjoy the learning.

\section{BIBLIOGRAPHY}

American Lit and Comp, period 1 \& 5, Ms Tucker.2000, (online), (http://www.educationworld.com/a_curr/strategy/strategy016.shtml on July, 232012

Buehl, Doug. 2001. Classroom Strategies for Interactive Learning; Second Edition (pg. 121). Newerk, Delaware: International Reading Association.

Depdikbud. 2009. Format laporan Akhir. Jakarta: Dirjen Dikti

Gay, L.R. 1981. Educational Research. Columbus. Charles E Merill Publishing Company.

Goodman. 1988. Ten Steps to Building College Reading Skills. Townsend: Townsend Press.

Harmer, Jeremy. 1991. The practice of English Language Teaching. New York: Longman Group UK Limited.

Hasriani. 2007. The Effectiveness of Using Look and Say Method in Increasing Student's Reading Skill. Thesis UIN Makassar.

Limpo, Amin. 2012. Rubric literal dan interpretive reading comprehension (online). http://socyberty.com/rubric-literal-dan-interpretive-reading.html/ on October 10, 2012.

Pang S., Elizabeth. 2003. Reading Comprehension Oxford: Pergamon.

Royer et. al., and Taglieber et.al. (1983). Pre-question strategy, (online), http://muttaqinhasyim.wordpress.com/pre-questioning/ on October 12, 2012 